\title{
1. Marx and the monetary business cycle
}

In the course of developing the ideas that were to become his comprehensive study of capitalist economic relations and dynamics in Capital, Marx had to confront the commonly observed coincidence of economic slump with banking crisis. This had given rise to a conviction that economic crisis was caused by the mismanagement of the monetary system. This view had become common among political economists and critics of capitalism with the emergence of more or less regular business cycles since the early nineteenth century. The key, therefore, to stabilisation of capitalist production and trade is a reform of the monetary system. It remains common today, uniting conservatives with some of capitalism's bitterest critics. Marx confronted these ideas in a first attempt at a comprehensive analysis of capitalism, his Grundrisse der Kritik der Politischen Ökonomie (Rohentwurf). ${ }^{1}$ This is a work of extraordinary range which allows it to be read in a number of different ways. The first, and probably the most obvious reading, is as a set of preliminary, transitional notes for the work that was to become Capital. A second reading that attracted widespread interest when the book was published, was as a philosophical introduction to Marx's critique of political economy, outlining the method that Marx was to use in his economic analysis (or not, according to the followers of Louis Althusser). Not least among the important features of the book, in this author's opinion, is a tantalising fragment, a mere few hundred words, on Greek art. ${ }^{2}$

However, the key to understanding the book is given in the chapter titles. A methodological introduction is followed by a chapter on money, and then a very extensive chapter, that takes up the vast bulk of a very long book, on capital. The purpose of this arrangement is to show that the monetary appearance of objects and relations is illusory, because capital is a social relationship, not a pecuniary one. Hence the phrase that recurs in the titles that Marx gave to his writings on political economy: the critique of political economy, rather than a helpful guide to correct doctrines in political economy. This accounts for much of the difficulty 
that arises in reading Marx's writings on political economy. Those works can only be fully understood by first reading the works that Marx was criticising. A first approximation may be obtained by reading the three volumes of Theories of Surplus Value. However, the task can be made much simpler by concentrating on a key theme of current significance that occurs in the Grundrisse and in Capital, namely the role that credit plays in capitalist production and crisis.

The chapter is organised as follows. A first section examines Marx's views on credit as presented in the Grundrisse. This is then contrasted, in the second section, with a more mature view on credit cycles, presented in Volume III of Capital. A third section argues that the two views are consistent with a historical view of the evolution of finance. A brief conclusion summarises the argument.

\subsection{REJECTING THE MONETARY BUSINESS CYCLE ...}

The first chapter of the Grundrisse, on Money, begins with a quotation from a book, De la réforme des banques by Alfred Darimon:

The root of the evil is the predominance which opinion obstinately assigns to the role of the precious metals in circulation and exchange.

Darimon (1819-1902), a journalist and politician, and follower of social philosopher and critic Pierre Joseph Proudhon, was what Keynes called a 'monetary reformer', i.e. a theorist who argues that the inadequacies of capitalism may be removed by reforming the monetary system. In Darimon's case, the reform he sought was joint stock banking backed by credit insurance. This he believed would provide the flexible credit supply that would prevent the financial crises that plagued France (and Britain) in the first half of the nineteenth century as a result of the use of precious metals to back bank credit.

Marx proceeded to castigate Darimon for his weak understanding of bank credit: 'he completely identifies monetary turnover with credit'. (In an aside that could be addressed to certain twenty-first century Marxist monetary theorists, Marx went on to remark 'The notion of crédit gratuit, incidentally, is only a hypocritical, philistine and anxiety-ridden form of the saying: property is theft. Instead of the workers taking the capitalists' capital, the capitalists are supposed to be compelled to give it to them'.) $)^{3}$ 
Marx identified 'the fundamental question' as:

Can the existing relations of production and the relations of distribution which correspond to them be revolutionised by a change in the instrument of circulation, in the organisation of circulation? ... Various forms of money may correspond better to social production at various stages; one form may remedy evils against which another is powerless; but none of them, as long as they remain forms of money, and as long as money remains an essential relation of production, is capable of overcoming the contradictions inherent in the money relation, and can instead only hope to reproduce these contradictions in one or another form. One form of wage labour may correct the abuses of another, but no form can correct abuse of wage labour itself. ${ }^{4}$

Marx's argument was essentially that crises occur because of contradictions in production and exchange, rather than in the medium of exchange: The 'bullion drains' (loss of gold from the banking system) that cause financial crises are themselves the results of changes in real, non-monetary, factors such as 'domestic harvest failures in a chief food crop (e.g. grain), crop failure abroad and hence increased prices in one of the main imported consumer goods (e.g. tea) ... crop failure in industrial raw materials (cotton, wool silk, flax etc.), excessive imports (caused by speculation, war etc.) ...' with the consequence that 'a part of (the nation's) invested capital or labour is not reproduced - real loss of production'. ${ }^{5}$

Marx then went on to argue that money prices could not measure the true price of commodities, but 'labour money denominated in labour time would ... equate the real value (exchange value) of commodities'. ${ }^{6}$ This early Marx reappears in Emile Zola's extraordinary novelistic treatment of financial crisis, L'Argent, as the 'Karl Marxite' Sigismund Busch, devoting his dying years to the calculation of a system of prices that would correspond to labour time, and that would therefore eliminate exploitation. This endeavour was then revived by those Marxian economists who have devoted themselves to the solution of the so-called 'transformation problem'?

The remainder of the chapter is devoted to contrasting and criticising the presumed intrinsic value of precious metals, as opposed to the social character of capitalist production and hence prices. This is therefore the prelude to Marx's very long chapter on capital. 


\section{2 ... ONLY TO EMBRACE THE MONETARY BUSINESS CYCLE ...}

There is no doubt that the chapter on money is inadequate. It is unsystematic, consisting of notes that break off inconclusively, and arguments criss-crossed with Marx's invective against Darimon, extended to Saint-Simonians such as Isaac Pereire. ${ }^{8}$ A serious gap in Marx's argument is the absence of any general account of economic or financial crisis. As indicated above, Marx suggested that crises were caused by real factors, disrupting production, but that the causes of any given financial crisis were particular to that crisis.

This lacuna was made up less than a decade later when Marx drafted Volume III of Capital. In this volume he introduced corporate finance into his argument in the guise of 'interest-bearing capital', a separate kind of money capital that emerges to finance production. ${ }^{9}$ This allowed Marx to distinguish between bank crises, caused by 'bullion drains' and problems that arise with refinancing industrial credit, or 'interest-bearing capital'. These problems arise because industrial credit is put into production. At this point the industrial capitalist no longer has the money, obtained when the credit was advanced, with which to repay that credit. That money had been used to buy means of production, the revenue from which is insufficient for immediate repayment of the credit advanced. ${ }^{10}$

In modern terminology, the process of production and (real) capital accumulation requires the purchase of illiquid assets using credit. This was identified as a feature of a Keynesian theory of crisis by Hyman P. Minsky:

The process of selling financial assets or liabilities to fulfill cash-payment commitments is called 'position-making' the position being the unit's holdings of assets which, while they earn income, do not possess markets in which they can be readily sold. For corporations the 'position' which has to be financed is the capital assets necessary for production; for financial firms, the 'position' is defined by the assets with poor secondary markets ... the owners of (industrial) capital-assets speculate by debt-financing investment and positions in the stock of capital-assets ...

Such firms 'with elaborated liability structures develop cash payment commitments which exceed the cash receipts they will get over the short period from contracts they own, or from operations. To fulfill their cash-payment commitments, they must refinance by selling either their assets or their liabilities. ${ }^{11}$ 


\section{$1.3 \quad$... MAY BE DONE DIALECTICALLY}

There is a functionalist tendency among Marxist economists whose common weakness consists of illicitly generalising from some logical necessity of a particular model of capitalism. In one version of this, all capitalist phenomena are treated as somehow 'functional' for capitalism which, by implication, is deemed incapable of operating in an inefficient, or dysfunctional, way. This kind of analysis appeals to critics of capitalism who would hang their critiques on the obvious 'unfairness' of capitalism, or the seemingly intractable poverty existing in capitalist societies. Monetary and financial theory, in this kind of functionalism, emerges from an examination of the monetary and financing needs of capitalist production and exchange, and serves those needs logically because money and credit have no other function in the capitalist economy. (Examples of this kind of reasoning may be found most famously in Hilferding's Finance Capital, and, more recently, in the 'circuitist' theory of money, or among the contributions to Moseley 2005.) In another, weaker, version of this functionalism, the institutions of a capitalist society are judged according to how they contribute to the efficient functioning of the capitalist economy. This is notable in the French Regulationist school, or among their transatlantic intellectual cousins, the Social Structure of Accumulation school of American Marxists.

This functionalist approach does not really do full justice to Marx's historic dialectic which explains the apparent paradox of his rejection of any monetary business cycle in the Grundrisse only to embrace it in Volume III of Capital. In the earlier work, Marx was concerned to show that monetary relations could not explain capitalism, or be the foundation for it as a historical formation. In Volume III of Capital he showed how the need to finance industrial production brought about the historical emergence of 'interest-bearing capital'. ${ }^{12}$ The unjustly neglected Marxist monetary theorist Karl Niebyl was to show how the prodigious credit needs of factory production induced the financial innovations that came about in the latter half of the nineteenth century with the routine establishment of companies capable of issuing long-term financial liabilities. ${ }^{13}$

At first glance, Marx's and Niebyl's approaches are 'functionalist' in the sense that credit markets develop to satisfy the financing requirements of capitalist production. Industrial capitalism pre-dates capitalist financial markets. Hence finance cannot be the social foundation for capitalism, nor, according to the Grundrisse, can monetary relations 
be the ultimate explanation for fluctuations in capitalism as it emerges. The problem with the functionalist view is that finance does not exist just to serve industrial capitalism. If this were so, then the United States would today be an industrial super-power, instead of just a financial and military super-power. The central issue is that, having emerged to serve industrial capitalism, the financial markets then change that capitalism: financial markets become a much more liquid source of profit (if not surplus value: the squeeze imposed by high interest rates on the residual surplus value of the industrial capitalist, a jejune problem that belongs, as Marx rightly noted, to early capitalism, rather than our capitalism dominated by finance ${ }^{14}$ ). Historically interest-bearing capital, with credit inflation, became the means by which capitalism refocused on balance sheet restructuring as a source of cash flow rather than just production. In this way, financial innovation changed the nature and the financing needs of industrial capital.

The process by which capitalist production induced financial innovation to extend production but, ultimately, to corrupt capitalist production is a historic dialectic that Marx knew well. In his polemic against Lord Overstone, who had argued that interest rates were high because profits were high, Marx put forward the view that higher interest rates may be caused by greater demand for money capital to finance production, which production is then diminished by the higher interest rates. Marx dismissed Overstone in the following terms:

That anything can ultimately destroy its own cause is a logical absurdity only for the usurer enamoured of the high interest rate. The greatness of the Romans was the cause of their conquests, and their conquests destroyed their greatness. Wealth is the cause of luxury and luxury destroys wealth ... ${ }^{15}$

This logic is well applied to finance: Just because financial markets developed to finance industry does not mean that they remained in this ancillary position, or that they cannot depress capital accumulation or agitate capitalism with credit cycles. Too many Marxists and post-Keynesians share a neo-classical textbook view that is stuck in the primordial function of the financial markets. The radical political economist of finance re-examines the financial markets of today and how they alter the nature and dynamics of capitalism. 


\subsection{CONCLUSION}

In his Grundrisse Marx rejected monetary relations as the foundation and explanation for capitalism. However, monetary relations return in his theory of crisis, which is a kind of monetary business cycle à la Minsky. This apparent paradox may be explained by the dialectical role played by finance in the development of capitalism: The financing needs of capitalist production induce financial innovation ('interest-bearing capital') which comes to have a dominant, rather than a subordinate, role in relation to production. The dominance of finance allows credit cycles to determine the nature and dynamics of capitalism. Marx himself was to conclude that:

The social character of capital is first promoted and wholly realised through the full development of the credit and the banking system ... The distribution of capital as a special business, a social function, is taken out of the hands of the private capitalists and usurers. But at the same time, banking and credit thus become the most potent means of driving capitalist production beyond its own limits, and one of the most effective vehicles of crises and swindle. ${ }^{16}$

\section{NOTES}

1. Marx 1993.

2. Ibid., pp. 110-111.

3. Ibid., p. 123.

4. Ibid.

5. Ibid., p. 127.

6. Ibid., p. 137.

7. Cf. Bellofiore 1989.

8. The banking doctrines of the Saint-Simonians are further discussed in Toporowski 2002, part 1 .

9. Marx 1959, part V.

10. Ibid., pp. 488-493.

11. Minsky 1975 , pp. 123-124.

12. Marx 1959, chapters XXI and XXV.

13. Niebyl 1946. Engels alludes to this in the brief chapter he wrote on the stock exchange to conclude Volume III of Capital.

14. See Marx 1959, pp. 109-110.

15. Ibid., p. 422.

16. Ibid., p. 607. 